\title{
Planning of pomegranate (Punica granatum L.) orchards management for season December-July (Ambe bahar)
}

A.D. BHAGAT AND P.G. POPALE

Received : $30.12 .2015 ;$ Revised : 27.08.2016; Accepted : 12.09.2016

See end of the Paper for authors' affiliation

Correspondence to :

\section{A.D. BHAGAT}

Department of Irrigation and Drainage Engineering, Mahatma Phule Krishi Vidyapeeth, Rahuri, AHMEDNAGAR (M.S.) INDIA

Email : arunbhagat02@ gmail.com
- ABSTRACT : The study was carried out to evaluate the Ambe bahar of pomegranate for optimum production of pomegranate for Solapur district in the semi-arid zone of Maharashtra. Generally, for crop planning, rainfall analysis and water balance studies are required, to determine drought investigation, water requirement and water surplus/ deficit for better management of orchards. Rainfall is the major determinant of pomegranate production, especially in rain fed areas because the contribution of rain fed horticulture is almost half to the national production. Therefore, an attempt has been made to estimate the occurrence of drought. Data are classified into certain degrees of drought severity (Drought, normal and surplus) based on a number of truncation levels corresponding to specified mean values of the rainfall. Pomegranate evapotranspiration determined by the crop co-efficient $(\mathrm{kc})$ approach where the effects of various weather conditions were incorporated into reference crop evapotranspiration and crop characteristics into crop co-efficient. The water to be applied through drip system at 90 per cent efficiency to pomegranate plantation spaced at $3 \times 4.5 \mathrm{~m}$. The water balance parameters and climatic shift in Ambe bahar of pomegranate for 14 stations of Solapur district were estimated.Thus, the study revealed that the average intensity of drought for all stations was higher in Ambe season (bahar) followed by Hasta and Mrig seasons (bahars) of pomegranate. For Ambe bahar, the total amounts of water to be applied is $16961 /$ tree for the pomegranate tree of $5^{\text {th }}$ year age at 70 per cent probability level for Solapur district. The average climate during season January-August (Ambe bahar) is arid with very poor moisture adequacy index but it is beneficial for quality and disease free production of pomegranate. The average moisture index was -78.31 per cent with highest and lowest moisture index were observed in Solapur (-72.77) and Mangalvedha (-81.96) stations, respectively. Thus, it concludes, good season for disease free, quality and more beneficial production of pomegranate when external source of water supply is available.

- KEY WORDS : Ambe bahar, Drought, Water deficit, Surplus, Climate shift

- HOW TO CITE THIS PAPER : Bhagat, A.D. and Popale, P.G. (2016). Planning of pomegranate (Punica granatum L.) orchards management for season December-July (Ambe bahar). Internat. J. Agric. Engg., 9(2) : 173-183, DOI: 10.15740/HAS/IJAE/9.2/173-183. 